九州大学学術情報リポジトリ

Kyushu University Institutional Repository

Formation of Porous Epoxy Micro-beads from a Single Droplet of Epoxy-Polyamide-Ammonium Bicarbonate at Different Temperatures

Leemsuthep, Anusha

Faculty of Chemical Engineering Technology, Universiti Malaysia Perlis (UniMAP)

Zakaria, Zunaida

Faculty of Chemical Engineering Technology, Universiti Malaysia Perlis (UniMAP)

Tanrattanakul, Varaporn

Sino-Thai International Rubber College, Research and Development Office

Du Ngoc Uy Lan

Department of Polymer Engineering, University Bayreuth, Bayreuth, Germany

https://doi.org/10.5109/4480710

出版情報 : Evergreen. 8 (2)，pp.328-334，2021-06. Transdisciplinary Research and Education Center for Green Technologies, Kyushu University

バージョン :

権利関係 : 


\title{
Formation of Porous Epoxy Micro-beads from a Single Droplet of Epoxy-Polyamide-Ammonium Bicarbonate at Different Temperatures
}

\author{
Anusha Leemsuthep ${ }^{1,2}$, Zunaida Zakaria ${ }^{1,2, *}$ Varaporn Tanrattanakul ${ }^{3}$, Du Ngoc \\ $\mathrm{Uy} \mathrm{Lan}^{4}$ \\ ${ }^{1}$ Faculty of Chemical Engineering Technology, Universiti Malaysia Perlis (UniMAP), Perlis, Malaysia \\ ${ }^{2}$ Geopolymer and Green Technology, Centre of Excellent (CEGeoGTech), Universiti Malaysia Perlis \\ (UniMAP), Perlis, Malaysia \\ ${ }^{3}$ Sino-Thai International Rubber College, Research and Development Office, Prince of Songkla University, \\ Hat Yai, Songkhla, Thailand. \\ ${ }^{4}$ Department of Polymer Engineering, University Bayreuth, Bayreuth, Germany
}

*Author to whom correspondence should be addressed:

Email: zunaida@unimap.edu.my

(Received December 31, 2020; Revised April 6, 2021; accepted April 14, 2021).

\begin{abstract}
Process temperature greatly affects the decomposition behavior of a blowing agent, and changes the structure of the porous epoxy. This paper investigates the effect of processing temperature on the decomposition rate and volume of decomposing gases from ammonium bicarbonate as well as the properties of porous epoxy micro-bead through a single epoxy droplet. A single epoxy droplet (epoxy-polyamide-ammonium bicarbonate) was dropped into the corn oil heated at the temperatures of $80^{\circ} \mathrm{C}, 90^{\circ} \mathrm{C}$ and $100^{\circ} \mathrm{C}$. This study found that by controlling the processing temperature, an epoxy foam bulk $\left(80^{\circ} \mathrm{C}\right)$ or a number of porous epoxy micro-beads were fabricated $\left(90^{\circ} \mathrm{C}\right.$ and $\left.100^{\circ} \mathrm{C}\right)$. Higher total volume of gas was generated which was $1142.86 \mathrm{~cm}^{3} / \mathrm{g}$ at $100^{\circ} \mathrm{C}$, with lower viscosity of epoxy. Therefore, the initial epoxy droplet of 10:6 ratio burst into smaller micro-beads with dominant sizes in the range of 251-500 $\mu \mathrm{m}$ and porosity of $30 \%$. From the perspective of epoxy polyamide ratios, the 10:10 ratio has porous epoxy micro-beads slightly larger than that of 10:6 ratio. This induced a decrease in porosity and an increase in specific gravity of micro-beads of 10:10 ratio.
\end{abstract}

Keywords: blowing agent, decomposition rate, emulsion, particle size, stoichiometric

\section{Introduction}

Porous micro-bead is considered to be a useful invention that has gained the attention of researchers recently. Due to the presence of pores in the structure, porous micro-bead offers large surface area ${ }^{1)}$, lightweight ${ }^{2)}$, excellent thermal properties ${ }^{3)}$ and enhanced absorption behavior ${ }^{4}$. As a result, porous micro-bead has been widely used in many applications including electronics ${ }^{5)}$, biomedical ${ }^{6}$, cosmetics ${ }^{7)}$, and automotive ${ }^{8)}$. The development of porous micro-bead is continuously improved to meet the desired applications.

Previously, different fabrication methods have been used to produce porous micro-bead such as suspension ${ }^{9}$, precipitation ${ }^{10)}$ and emulsification methods ${ }^{11}$. Among these methods, the emulsion method is the most suitable technique to obtain high porosity and to control the beadsize. Emulsion is a system consisting of two or more immiscible liquid phases, wherein one liquid is dispersed in the other liquid phase ${ }^{12}$. Nayan et al. ${ }^{11)}$ reported that the emulsion method is a simple and economic method to produce micro-bead. In the study, they added porofor toluenesulfonylhydrazide 75 (Porofor TSH) as a blowing agent in the epoxy droplet. In addition, Leemsuthep et al. 13) also used sodium bicarbonate as a blowing agent to fabricate porous micro-bead through emulsion method. These two types of blowing agents require higher temperatures to decompose.

Blowing agents introduce a cellular structure to the polymer matrix through the foaming process ${ }^{14}$ ). Thermal blowing agents decompose and produce gases after receiving sufficient heat ${ }^{15}$. The gases generate pressure in the polymer matrix and initiate expansion. Each blowing agent has a specific range of decomposition temperature ${ }^{16)}$. Thus, it is important to investigate the optimum temperature of the blowing agent, which helps to obtain high porous micro-bead. The decomposition rate of the blowing agent plays the key role in this case. 
In this paper, ammonium bicarbonate $(\mathrm{AB})$ was used due to its low thermal decomposition temperature and low cost. Furthermore, due to its nontoxicity, $\mathrm{AB}$ is regarded as a more environmentally friendly blowing agent that can be used in the food ${ }^{17)}$ and pharmaceutical industries ${ }^{18)}$. The AB was added into the single epoxy-polyamide droplet and dropped in the corn oil heated at different temperatures. It was then decomposed at different rates which significantly affected the size of porous epoxy micro-bead from the single droplet. The investigation using single droplet clearly demonstrated the effect of $\mathrm{AB}$ which allowed the epoxy droplet expansion at $360^{\circ}$ in the oil without limitation in the use of a mould.

\section{Experimental}

\subsection{Materials}

Epoxy resin DER 331 and polyamide A062 were purchased from Euro Chemo Pharma Sdn Bhd, Malaysia. Epoxy resin DER 331 has density and viscosity of 1.16 $\mathrm{g} / \mathrm{cm}^{3}$ and $11-14$ Pas, respectively, at $25^{\circ} \mathrm{C}$. It has epoxide equivalent weight of 182-192. Polyamide A062 has equivalent weight per $\mathrm{H}$ active of 110 . The density and viscosity of polyamide $\mathrm{A} 062$ at $25^{\circ} \mathrm{C}$ were $0.96 \mathrm{~g} / \mathrm{cm}^{3}$ and 35-45 Pas, respectively. AB provided from HmbG Chemicals Malaysia was white crystalline powder used as the blowing agent and has density of $1.58 \mathrm{~g} / \mathrm{cm}^{3}$. Corn oil was purchased from Yee Lee Corporation Sdn. Bhd, Malaysia and has a viscosity of 50 Poise at $25^{\circ} \mathrm{C}$.

\subsection{Preparation of Porous Epoxy Micro-bead (PEMB)}

Two different epoxy:polyamide ratios of 10:6 (a stoichiometry ratio) and 10:10 (excess polyamide) were used. Initially, epoxy and 5 phr AB were mixed using an over-head stirrer with a speed of $300 \mathrm{rpm}$ for 3 minutes (phr = part per hundred resin + hardener). Polyamide was added sequentially and mixed at the speed of $300 \mathrm{rpm}$ for another $3 \mathrm{~min}$. Next, $0.1 \mathrm{ml}$ of epoxy mixture single droplet was dropped into $100 \mathrm{ml}$ heated corn oil as the emulsion medium in a measurement cylinder by using a 5 $\mathrm{ml} / \mathrm{cc}$ plastic syringe with $2 \mathrm{~mm}$ nozzle size. The corn oil was heated at different temperatures of $80^{\circ} \mathrm{C}, 90^{\circ} \mathrm{C}$ and $100^{\circ} \mathrm{C}$. The epoxy droplet was kept in the heated corn oil for 1 hour for foaming and curing processes. The porous epoxy micro-bead was collected and washed using detergent water ratio of $1: 20$ at $60^{\circ} \mathrm{C}$. Then, the microbead was dried at $80^{\circ} \mathrm{C}$ for 4 hours in a conventional oven.

\subsection{Testing and characterization}

To measure the decomposition rate and total volume of gas by $\mathrm{AB}, 2.4 \mathrm{mg}$ of $\mathrm{AB}$ was placed into the test tube, which was partially immersed in the heated corn oil as shown in Schematic 1 . The corn oil was heated at different temperatures $\left(80^{\circ} \mathrm{C}, 90^{\circ} \mathrm{C}\right.$ and $\left.100^{\circ} \mathrm{C}\right)$. The gas released through the hollow glass rod into the corn oil in the measuring cylinder was recorded. Five process cycles were repeated. The decomposition rate and total volume of gases generated by AB were measured by Eq. 1 and Eq. 2 .

$$
\begin{aligned}
& \text { decomposition rate }=\frac{\text { volume of } \text { water displacement }}{\text { time }} \\
& \text { total volume of gas }=\frac{\text { volume of water displacement }}{\text { mass of ammonium bicarbonate }}
\end{aligned}
$$

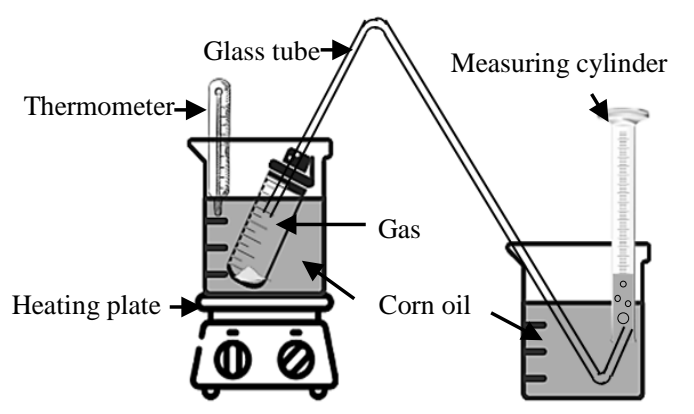

Schematic 1: Schematic diagram of the measurement of gas volume decomposed from $\mathrm{AB}$

Rheological behavior of the epoxy mixture was conducted by Anton Paar Physica MCR 301 rotational rheometer equipped with a $25 \mathrm{~mm}$ parallel plate and an aluminium tray with inner diameter of $55 \mathrm{~mm}$. The measured gap between the parallel plate and the aluminium tray was $1 \mathrm{~mm}$. The parallel plate was rotated at $5 \%$ strain. The test was conducted at Department of Polymer Engineering, University of Bayreuth.

The microstructure of porous epoxy micro-bead was observed and analysed using scanning electron microscopy (SEM) (model JEOL JSM 6460 LA). The samples were coated with platinum by a sputter coating instrument (Bio-Rad Polaran Division) to avoid electrostatic charging during observation.

Dino-lite Digital Microscope model AM5216ZT Edge Series (Perlis, Malaysia), equipped with a low-resolution digital camera using Dino Capture 2.0 software was used to capture the image of the particles. This image was then analyzed using ImageJ software to measure the average particle size.

Porosity of porous epoxy micro-bead was determined using simple method as described in Eq. 3.

$$
\text { Porosity }=1-\frac{\text { Bead Specific Gravity }}{\text { Solid Specific Gravity }} \times 100
$$

\section{(3)}

Specific gravity of porous epoxy micro-bead was determined according to ASTM D854-14 usingpycnometer bottle to calculate the specific gravity of the sample using water displacement method. The specific 
gravity (SG) of porous epoxy micro-bead was calculated by weight according to Eq. 4.

$$
S G=\frac{W_{2}-W_{1}}{\left(W_{2}-W_{1}\right)-\left(W_{3}-W_{4}\right)}
$$

where, SG is specific gravity, $\mathrm{W}_{1}$ is mass of pycnometer bottle in $g, W_{2}$ is mass of pycnometer bottle filled with sample in $\mathrm{g}, \mathrm{W}_{3}$ is mass of pycnometer bottle filled with sample and water in $\mathrm{g}$, and $\mathrm{W}_{4}$ is mass of pycnometer bottle filled with water in g. Five cycles of process were repeated.

\section{Results and discussion}

\subsection{Decomposition rate and total volume of gas generated}

Fig. 1 demonstrates the decomposition rate of $\mathrm{AB}$ for completing its exothermic decomposition reaction and total volume of gas generated by $\mathrm{AB}$ at different process temperatures. As expected, the decomposition rate of $\mathrm{AB}$ increased significantly from $1.19 \times 10^{-3} \mathrm{~cm}^{3} \mathrm{~s}^{-1}$ at $80^{\circ} \mathrm{C}$ to $5.00 \times 10^{-3} \mathrm{~cm}^{3} \mathrm{~s}^{-1}$ at $100^{\circ} \mathrm{C}$. Higher temperature provides more kinetic energy to activate the reaction rate of $A B{ }^{19}$. This situation is similar to that of Orr et al. which verified that temperature is one of the parameters influencing the chemical reaction by shifting the relative speed of the reaction ${ }^{20)}$.

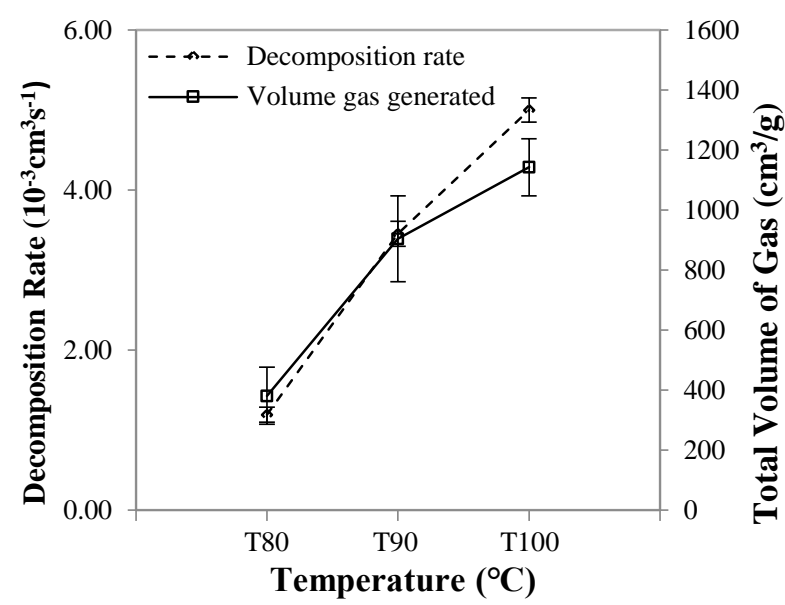

Fig. 1: Decomposition rate of $\mathrm{AB}$ and total volume of gas generated at different process temperatures

Furthermore, the total volume of gas generated after completing the decomposition reaction increased from $380.95 \mathrm{~cm}^{3} / \mathrm{g}$ to $1142.86 \mathrm{~cm}^{3} / \mathrm{g}$ at the same amount of blowing agent used. Theoretically, the same amount of AB would produce the same mole of gases; however, the higher temperature, the greater the volume of gas decomposed. These results definitely will affect the foaming process of a single epoxy droplet.

\subsection{Rheological behavior}

The rheological behaviors of epoxy-polyamide-AB and epoxy-polyamide at $100^{\circ} \mathrm{C}$ for $10: 6$ and $10: 10$ ratios are depicted in Fig. 2(a) and Fig. 2(b), respectively. The results indicated a clear foaming stage after gel points at $10: 6 \_5 \mathrm{AB}$ and 10:10_5AB. The presence of $\mathrm{AB}$ accelerated the gel time. In detail, the gel time was $3.4 \mathrm{~min}$ for 10:6_5AB and $7.0 \mathrm{~min}$ for 10:6_0AB, while the gel time was $3.9 \mathrm{~min}$ for $10: 10 \_5 \mathrm{AB}$ and $7.0 \mathrm{~min}$ for $10: 10 \_0 \mathrm{AB}$. In addition, the gel viscosity of 10:6_0AB was 606.1 Pas and 10:10_0AB was 1070.0 Pas. It was interesting to find that $A B$ also induced the gel viscosities of 10:6_5AB (8.22 Pas) and 10:10_5AB (8.29 Pas) to be almost similar. During foaming, the storage modulus of $10: 6 \_5 \mathrm{AB}$ was plateau and its loss modulus decreased but the storage modulus of 10:10_5AB slightly increased and its loss modulus was plateau. This may be due to the presence of more primary amines ${ }^{21)}$ in 10:10 ratio to react with epoxy and thus increased the storage modulus during foaming for 10:10_5AB and also resulted in higher gel viscosity for 10:10_0AB.

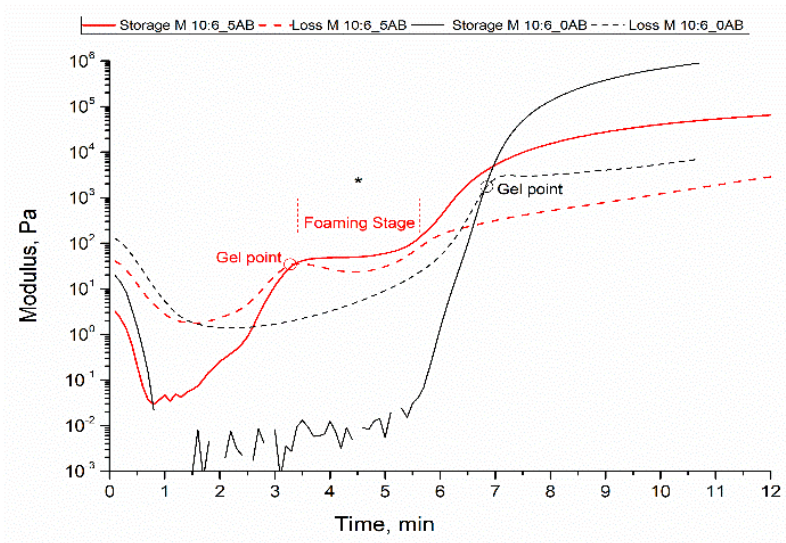

Fig. 2(a): Rhelogies of 10:6_5AB and 10:6_0AB at $100^{\circ} \mathrm{C}$

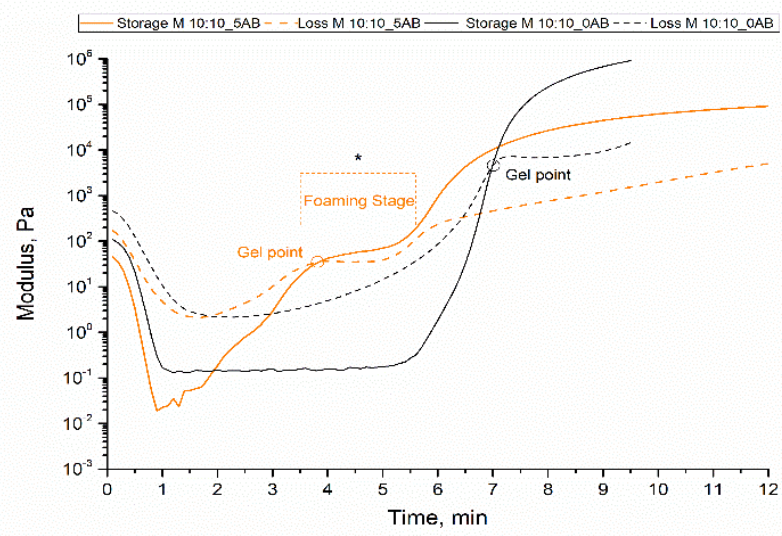

Fig. 2(b): Rhelogies of 10:10_5AB and 10:10_0AB at $100^{\circ} \mathrm{C}$ 


\subsection{Morphology analysis}

The single droplet without $\mathrm{AB}$ remained as one particle after curing with size of $8.86 \mathrm{~mm}$ for $10: 6$ ratio and 8.37 $\mathrm{mm}$ size for 10:10 ratio. The droplets with $\mathrm{AB}$ are shown in Fig. 3. At $80^{\circ} \mathrm{C}$, the single droplet of 10:6 ratio formed one foam bulk of $9.66 \mathrm{~mm}$ size, while the 10:10 ratio formed one foam bulk of $11.62 \mathrm{~mm}$ size as a result of a common foaming process. At $90^{\circ} \mathrm{C}$, many macro-beads were formed for both epoxy formulas, while more microbeads were obtained at $100^{\circ} \mathrm{C}$. The micro-beads of $10: 6$ ratio could be smaller than that of 10:10 ratio. These results are supported by higher decomposing rate and greater gas volume at higher process temperatures. Furthermore, the viscosity of the epoxy could reduce with higher process temperature $\left(100^{\circ} \mathrm{C}\right)$ so that the single droplet could burst into many small droplets.

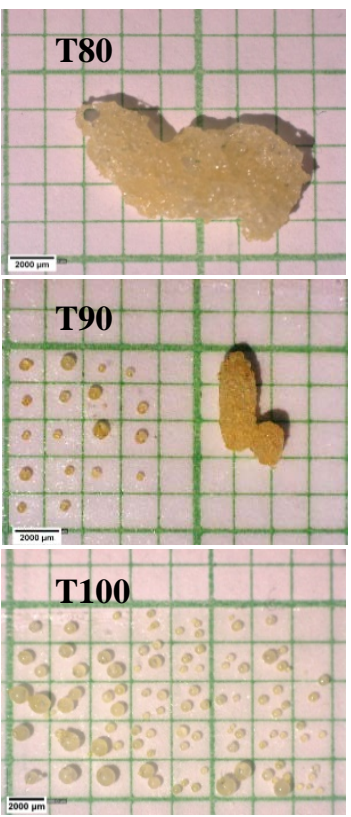

10:6
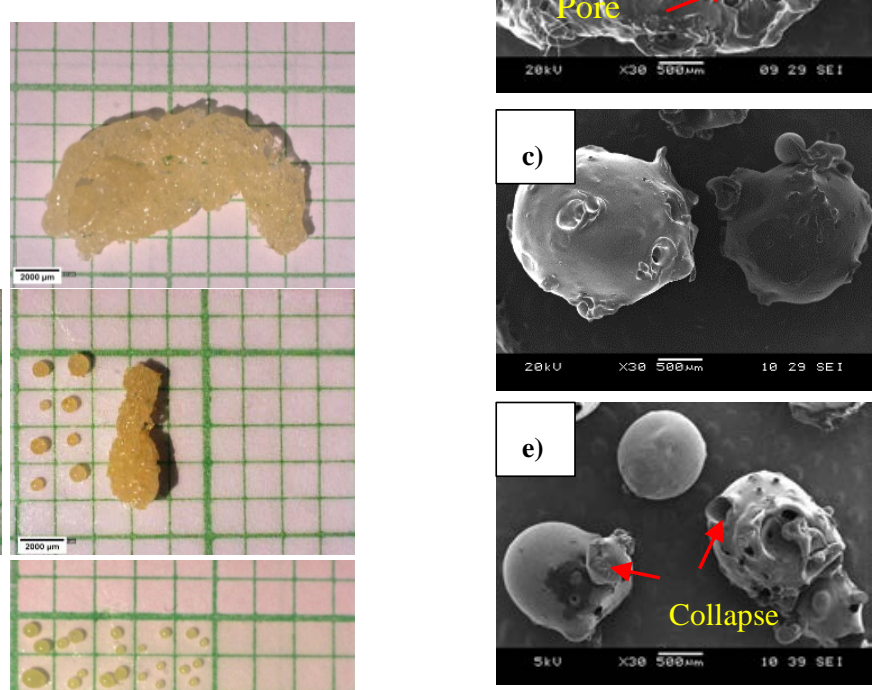

temperature, it was able to produce various porous epoxy micro-beads or bulk foams.

It was also found that the epoxy:polyamide ratio of 10:10 offered larger particle size compared to 10:6. The rheology of 10:6_5AB showed a plateau storage modulus and a decrease in loss modulus during foaming. This was evidenced for 10:6_5AB having a number of micro-beads. Excess polyamide ratio of 10:10 could result in more primary amines and epoxy reactions to increase the viscosity and modulus as shown in Fig. 2(b) (as clarified by Fauzi et al. ${ }^{22)}$. Therefore, the $10: 10$ ratio produced more and larger macro-beads.
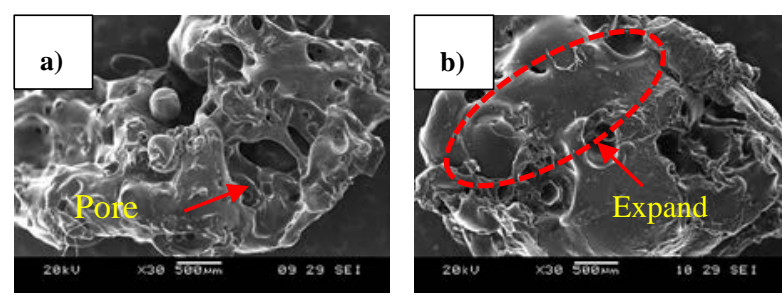

Fig. 4: SEM images of porous epoxy micro-beads for (a) 10:6_T80 (b) 10:10_T80 (c)10:6_T90 (d) 10:10_T90 (e)10:6_T100 and (f)10:10_T100

\subsection{Particle Size}

The effect of process temperature at $90^{\circ} \mathrm{C}$ and $100^{\circ} \mathrm{C}$ on the particle size was visible for both 10:6 and 10:10 ratios. As seen in Fig. 5(a), the number of micro-beads with sizes below $250 \mu \mathrm{m}$ produced by 10:6_T90 was significantly lower than that of 10:6_T100. It was found that the microbead sizes in the range of $251-500 \mu \mathrm{m}$ were predominant in both 10:6_T90 and 10:6_T100. Moreover, 10:6_T90 has more micro-beads in the size range of $501-750 \mu \mathrm{m}$ compared to the size range of $0-250 \mu \mathrm{m}$. In contrast, 10:6_T100 has a fairly low number of micro-beads sized between 501 - $750 \mu \mathrm{m}$. Furthermore, 10:6_T90 also has bulk micro-beads sizing $7.0 \mathrm{~mm}$, while 10:6_T90 has the largest micro-beads of $1250 \mu \mathrm{m}$ or $1.25 \mathrm{~mm}$. This could be due to the vigorous decomposition of $\mathrm{AB}$ occurred at a temperature of $100^{\circ} \mathrm{C}$ producing a mixture of ammonia gas, carbon gas and vapour in the epoxy droplet. In addition, the viscosity of the epoxy droplet was also lower at $100^{\circ} \mathrm{C}$ compared to $90^{\circ} \mathrm{C}{ }^{23)}$. Therefore, 10:6_T100 
obtained more smaller micro-beads compared to 10:6_T90.

Similar trend also occured to the epoxy-polyamide of 10:10 ratio. As observed in Fig. 5(b), 10:10_T90 has larger micro-beads compared to 10:10_T100. Although 10:10_T90 exhibited absence of micro-bead sizes below $250 \mu \mathrm{m}$, the sizes ranging between $250-500 \mu \mathrm{m}$ were dominant. 10:10_T90 also has micro-beads in the range of $750-1000 \mu \mathrm{m}$, and bulk in $8.0 \mathrm{~mm}$ size. For 10:10_T100, the dominant micro-bead size range was $250-500 \mu \mathrm{m}$ whose frequency was twice than that of the frequency for the size ranges of $0-250 \mu \mathrm{m}$ and $501-750 \mu \mathrm{m}$.
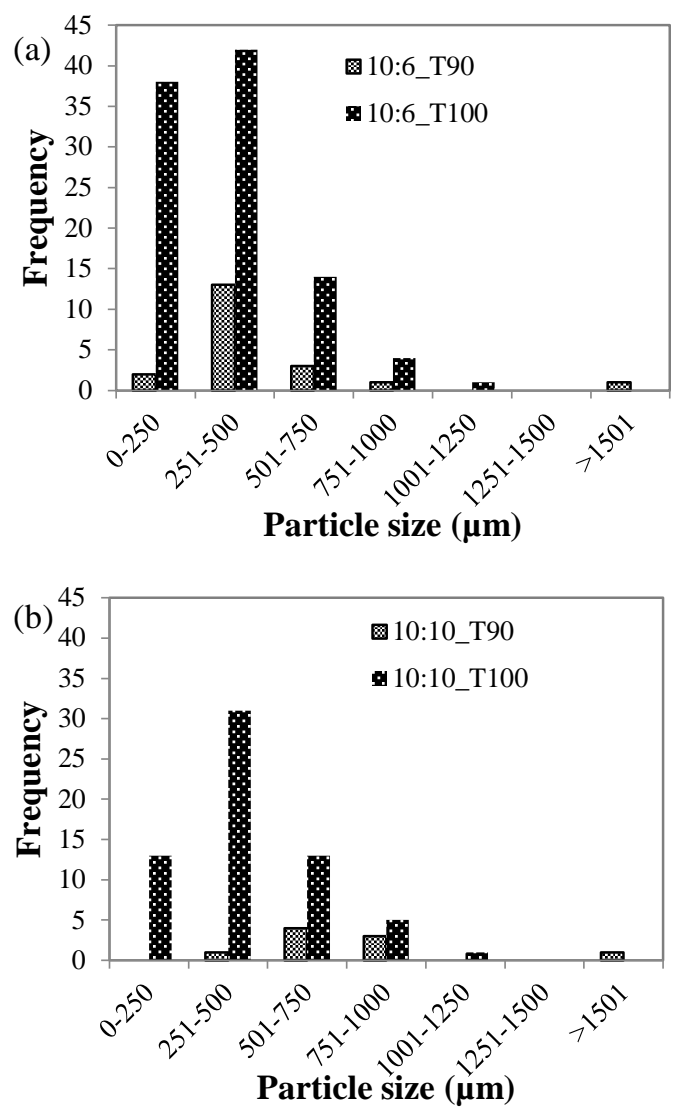

Fig. 5: Particle size distribution of porous micro-beads at $90^{\circ} \mathrm{C}$ and $100^{\circ} \mathrm{C}$ obtained from single droplet of epoxy-polyamide-

$\mathrm{AB}$ at (a) 10:6 ratio and (b) 10:10 ratio

The particle size of the micro-beads for 10:10 ratio was larger than the 10:6 ratio. In detail, 10:6_T90 has microbead size below $250 \mu \mathrm{m}$ but 10:10_T90 has none. The dominant sizes of micro-beads were in the range of 251 $500 \mu \mathrm{m}$ for 10:6_T90 and 501 - $750 \mu \mathrm{m}$ for 10:10_T90. When the process was carried out at $100^{\circ} \mathrm{C}$, both 10:6_T100 and 10:10_T100 have similar size distribution and dominant size range of $251-500 \mu \mathrm{m}$. The main difference was that the frequency for $0-250 \mu \mathrm{m}$ size range for 10:6-T100 was twice than that of 10:100-T100 as shown in Fig. 5(a) and Fig. 5(b).

\subsection{Porosity and specific gravity}

Fig. 6 shows the relationship between porosity and process temperature with epoxy polyamide ratio. It was indicated that high process temperature produced high porosity of porous epoxy micro-bead. High process temperature resulted in vigorous liberation of gas (Fig. 1). This is in agreement with Antonio et al. ${ }^{24)}$ where high quantity of gas decomposed from $\mathrm{AB}$ could increase the number of pore cells in the polymer. This is also emphasized by Najib et al. ${ }^{25)}$. For this reason, the porous epoxy micro-bead has higher porosity.

The difference in epoxy polyamide ratio affected the porosity, where 10:6 ratio exhibited higher porosity compared to 10:10 ratio. More polyamide led to higher initial viscosity and higher modulus during foaming but fewer expansion. Therefore, 10:10 ratio has lower porosity compared to $10: 6$ ratio at the same process temperature.

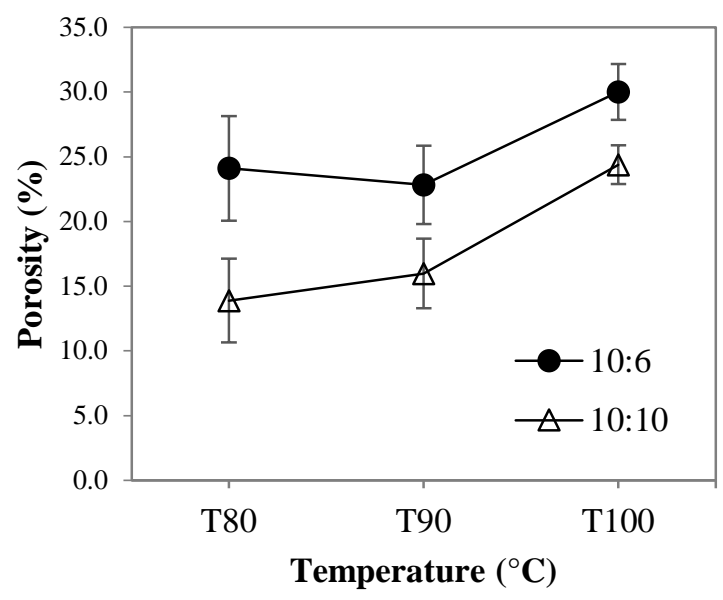

Fig. 6: Porosity of porous epoxy micro-bead for different process temperatures and epoxy polyamide ratios

Fig. 7 shows the specific gravity of porous epoxy micro-bead at different process temperatures and epoxy polyamide ratios. The specific gravity of porous epoxy micro-bead decreased with increasing process temperature which can be explained by the microstructure and particle size of porous epoxy micro-bead as depicted in Fig. 4. In addition, higher process temperatures promoted higher porosity and this was supported by Fig. 6.

As stated by Antonini et al. ${ }^{26)}$ and Baskoro et al. ${ }^{27)}$, high porosity offers low specific gravity due to the structure of polymer. This supported the results obtained in this study where the epoxy:polyamide ratio of 10:6 with high porosity has low specific gravity and vice versa for 10:10 ratio. 


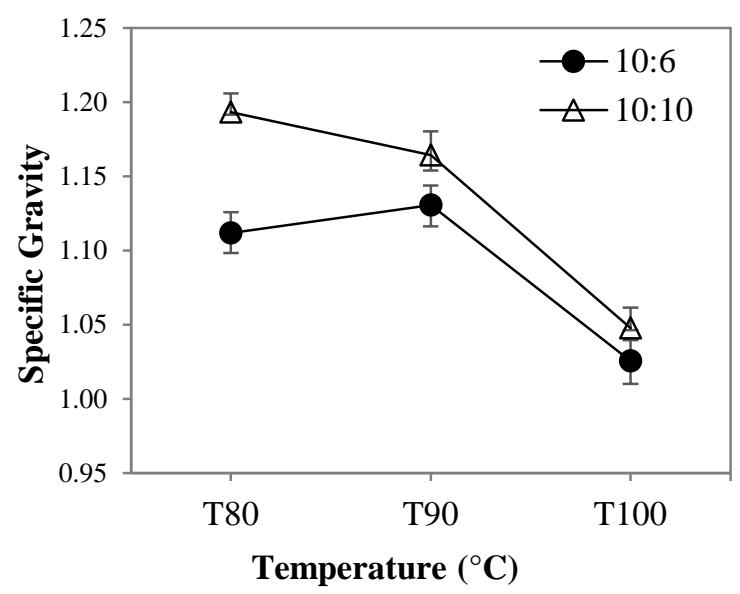

Fig. 7: Specific gravity of porous epoxy micro-bead for different process temperatures and epoxy polyamide ratios

\section{Conclusion}

The role of blowing agent is essential in the production of epoxy porous micro-beads. The most important factor is the process temperature, which controls the decomposition rate and gas volume of the blowing agent. These features were significantly observed when the single droplet of epoxy-polyamide was used. Ammonium bicarbonate was found to form bulk epoxy foam at $80^{\circ} \mathrm{C}$. The optimum process temperature was $100^{\circ} \mathrm{C}$, which produced porous epoxy micro-beads below $500 \mu \mathrm{m}$ with the porosity of up to $30 \%$. The epoxy:polyamide stoichiometric ratio of 10:6 exhibited smaller particle size and higher porosity with lower specific gravity than the excess polyamide ratio of 10:10. This study could be applied in the production of porous epoxy micro-beads as well as the functional epoxy micro-beads such as conductive or toughening functionality.

\section{Acknowledgements}

The authors would like to thank University Malaysia Perlis for providing machinery and equipment involved in this research. We also would like to thank the technicians of the Faculty of Chemical Engineering Technology for their cooperation and assistance in performing experiments for this research.

\section{References}

1) R. Calmo, A. Chiadò, S. Fiorilli, and C. Ricciardi, "Advanced elisa-like biosensing based on ultralargepore silica microbeads,” ACS Appl. Bio Mater., 3 (9) 5787-5795 (2020).

2) Y. Zhu, Y. Zhao, and Q. Fu, “Toward uniform poresize distribution and high porosity of isotactic polypropylene microporous membrane by adding a small amount of ultrafine full-vulcanized powder rubber,” Polymer (Guildf)., 103 405-414 (2016).
3) A. Sharma, R. Kumar, V.K. Patle, R. Dhawan, A. Abhash, N. Dwivedi, D.P. Mondal, and A.K. Srivastava, "Phenol formaldehyde resin derived carbon-mcmb composite foams for electromagnetic interference shielding and thermal management applications,” Compos. Commun., 22100433 (2020).

4) J. Miyawaki, J. Yeh, H.S. Kil, J.K. Lee, K. Nakabayashi, I. Mochida, and S.H. Yoon, "Influence of pore size and surface functionality of activated carbons on adsorption behaviors of indole and amylase," Evergr. Jt. J. Nov. Carbon Resour. Sci. Green Asia Strateg., 3 (2) 17-24 (2016).

5) T. Jin, Y. Pan, G.J. Jeon, H.I. Yeom, S. Zhang, K.W. Paik, and S.H.K. Park, "Ultrathin nanofibrous membranes containing insulating microbeads for highly sensitive flexible pressure sensors," ACS Appl. Mater. Interfaces, 12 (11) 13348-13359 (2020).

6) Z. Zhou, W. Wu, J. Fang, and J. Yin, "Polymer-based porous microcarriers as cell delivery systems for applications in bone and cartilage tissue engineering," Int. Mater. Rev., 66 (2) 77-113 (2021).

7) C.A. King, J.L. Shamshina, O. Zavgorodnya, T. Cutfield, L.E. Block, and R.D. Rogers, "Porous chitin microbeads for more sustainable cosmetics,” ACS Sustain. Chem. Eng., 5 (12) 11660-11667 (2017).

8) J.K. Katiyar, S. Bhattacharya, V.K. Patel, and V. Kumar, “Automotive Tribology,” India, 2019.

9) X. Li, D. Yao, K. Zuo, Y. Xia, J. Yin, H. Liang, and Y.P. Zeng, "Microstructure and permeability of porous ysz ceramics fabricated by freeze casting of oil-in-water suspension,” J. Eur. Ceram. Soc., 40 (15) 5845-5851 (2020).

10) P. Karthikeyan, S. Vigneshwaran, J. Preethi, and S. Meenakshi, "Preparation of novel cobalt ferrite coated-porous carbon composite by simple chemical co-precipitation method and their mechanistic performance,” Diam. Relat. Mater., 108 (April) 107922 (2020).

11) N.A.M. Nayan, A. Leemsuthep, Z. Zakaria, and D.N. Uy Lan, "Preparation of epoxy composite hollow microspheres (ECHM) using toluenesulfonyl hydrazide (TSH) as blowing agent," Macromol. Symp., 371 (1) 94-100 (2017).

12) M. Kawaguchi, "Silicone oil emulsions stabilized by polymers and solid particles," Adv. Colloid Interface Sci., 1-14 (2015).

13) A. Leemsuthep, N.A. Mohd Nayan, Z. Zakaria, and D.N. Uy Lan, "Effect of sodium bicarbonate in fabrication of carbon black-filled epoxy porous for conductive application,” Macromol. Symp., 371 (1) 44-49 (2017).

14) Á. Kmetty, K. Litauszki, and D. Reti, "Characterization of different chemical blowing agents and their applicability to produce poly (lactic acid) foams by extrusion,” Appl. Sci., 8 (1960) (2018).

15) Á. Kmetty, and K. Litauszki, "Development of poly (lactide acid) foams with thermally expandable 
microspheres,” Polymer (Guildf)., 12 463-479 (2020).

16) A. Bisht, B. Gangil, and V.K. Patel, "Review article selection of blowing agent for metal foam production: a review,” J. Met. Mater. Miner., 30 (1) 1-10 (2020).

17) Y. Kim, J.H. Lee, Y.C. Kim, K.H. Lee, I.S. Park, and S.J. Park, "Operation and simulation of pilotscale forward osmosis desalination with ammonium bicarbonate," Chemical Engineering Research and Design, 94 390-395 (2015).

18) S. Bavarella, A. Brookes, A. Moore, P. Vale, G. Di Profio, E. Curcio, P. Hart, M. Pidou, and E.J. McAdam, "Chemically reactive membrane crystallisation reactor for CO2-NH3 absorption and ammonium bicarbonate crystallisation: Kinetics of heterogeneous crystal growth," Journal of Membrane Science, 599, 117682 (2020).

19) H.B. Sharma, S. Panigrahi, and B.K. Dubey, "Hydrothermal carbonization of yard waste for solid bio-fuel production: study on combustion kinetic, energy properties, grindability and flowability of hydrochar,” Waste Manag., 91 108-119 (2019).

20) R.M. Orr, H.E. Sims, and R.J. Taylor, “A review of plutonium oxalate decomposition reactions and effects of decomposition temperature on the surface area of the plutonium dioxide product," J. Nucl. Mater., 465 756-773 (2015).

21) F.N. Alhabill, R. Ayoob, T. Andritsch, and A.S. Vaughan, "Effect of resin/hardener stoichiometry on electrical behavior of epoxy networks,” IEEE Trans. Dielectr. Electr. Insul., 24 (6) 3739-3749 (2017).

22) M.S. Fauzi, D.N.U. Lan, H. Osman, and S.A. Ghani, "Effect of sodium bicarbonate as blowing agent on production of epoxy shape memory foam using aqueous processing method," Sains Malaysiana, 44 (6) 869-874 (2015).

23) A. Leemsuthep, Z. Zakaria, A.W.M. Kahar, and D.N.U. Lan, "Effect of emulsion temperature on properties of conductive epoxy porous prepared by single emulsion technique effect of emulsion temperature on properties of conductive epoxy porous prepared by single emulsion technique," IOP Conf. Ser. Mater. Sci. Eng., 429 1-6 (2018).

24) J. Antonio, R. Ruiz, M. Vincent, J. Agassant, C. Pillon, C. Carrot, J. Antonio, R. Ruiz, M. Vincent, J. Agassant, T. Sadik, and C. Pillon, "Polymer foaming with chemical blowing agents: experiment and modeling,” Polym. Eng. Sci., 55 (9) 2018-2029 (2015).

25) N.N. Najib, Z.M. Ariff, N. a Manan, a a Bakar, and C.S. Sipaut, "Effect of blowing agent concentration on cell morphology and impact properties of natural rubber foam,” J. Phys. Sci., 20 (1) 13-25 (2009).

26) C. Antonini, T. Wu, T. Zimmermann, and A. Kherbeche, "Ultra-porous nanocellulose foams : a facile and scalable fabrication approach," Nanomaterials, 9 1-14 (2019).
27) A.S. Baskoro, M.A. Amat, R.D. Putra, A. Widyianto, and Y. Abrara, "Investigation of temperature history, porosity and fracture mode on aa1100 using the controlled intermittent wire feeder method," Evergr. Jt. J. Nov. Carbon Resour. Sci. Green Asia Strateg., 7 (1) 86-91 (2020). 